\title{
Problem Penambangan Emas Tanpa Ijin Ditinjau Dari Aspek Pidana Lingkungan Hidup dan Etika
}

\author{
Dedy Syaputra \\ Fakultas Hukum Universitas Batanghari \\ Jalan Slamet Riyadi Broni Kota Jambi Telp: (0741) 65351 \\ Correspondence email: dedysyaputra83@gmail.com
}

\begin{abstract}
Abstrak. Terdapat beberapa kasus lingkungan di Provinsi Jambi diantaranya: kabut asap, kebakaran hutan, banjir, PETI (Penambangan Emas tanpa Ijin), dan lain sebagainya. Hal ini selalu terjadi pengulangan dari tahun ke tahun seolah-olah tidak memiliki solusi yang permanen. Dugaan penulis dalam hal ini disebabkan beberapa kemungkinan, yaitu: masyarakat tidak mengerti atau memahami apakah tindakannya (dalam konteks perusakan lingkungan) itu termasuk melanggar hukum pidana atau tidak? Dan atas dasar ketidatahuan masyarkat itu, sehingga ada anggapan bahwa apa yang mereka lakukan tidak bertentangan dengan hukum. Berdasarkan hipotesa di atas, maka penulis tertarik untuk menguraikan apa sebenarnya problemPETI ini dari perspektif hukum pidana dan etika. Sehingga diharapkan mampu mengedukasi masyarakat bahwa perbuatan tersebut ternyata sudah dapat dikatakan melanggar/tidak melanggar hukum pidana. Lalu, penulis mencoba menawarkan solusi preventif dari perspektif etis; yaitu apa yang dapat ditawarkan oleh filsafat moral agar kasus-kasus lingkungan dalam konteks hukum pidana tersebut dapat diatasi (dicegah) dengan semaksimal mungkin. Tulisan ini menggunakan pendekatan kualitatif dengan teknik analisis datanya menggunakan teknik konten analisis. Dengan pendekatan ini, diperoleh kesimpulan sebagai berikut: (1) Ancaman pidana sebagaimana tercantum dalam pasal-pasal adalah pidana penjara dan denda. Selain itu ada pidana tambahan atau tindakan tata tertib terhadap badan usaha Pasal 119 Undang-Undang Nomor 32 Tahun 2009 tentang Perlindungan dan Pengelolaan Lingkungan Hidup. Mengenai beberapa faktor yang menghambat dalam penegakan hukum yaitu sarana hukum, aparat penegak hukum, fasilitas dan sarana, perizinan, sistem AMDAL, kesadaran hukum masyarakat terhadap lingkungan. (2) Dalam pandangan Al-Ghazali manusia mempunyai fungsi, tugas dan tanggung jawab yang sangat berat yaitu sebagai pemelihara segala SDA (Sumber Daya Alam) yang ada di bumi ini. Ketika manusia memahami fungsinya di dunia ini adalah untuk memelihara lingkungan, maka secara otomatis, konsep moral ini akan menjadi langkah preventif atas kegiatan PETI yang nyata-nyata telah menyebabkan kerusakan lingkungan oleh manusia.
\end{abstract}

Keywords: Pidana Lingkungan, PETI, Etika

\begin{abstract}
There are several cases of environment in Jambi province including haze, forest fires, floods, PETI (gold mining without permits), and so forth. This is always the case of repetition from year to year as if it did not have a permanent solution. Alleged authors in this regard are some possibilities, namely: society does not understand or understand whether its actions (in the context of environmental destruction) that include violating criminal law or not? And on the basis of the community, so there is a notion that what they do is not contrary to the law. Based on the hypothesis above, the authors are interested in describing what exactly this Problembox is from the perspective of criminal law and ethics. So hopefully able to educate the community that the deed can be said to violate/not violate criminal law. Then, the author tries to offer a preventive solution from an ethical perspective; That is what the moral philosophy can offer so that the environmental cases in the context of the criminal law can be addressed to the fullest extent possible. This paper uses a qualitative approach with its data analysis techniques using analytical content techniques. With this approach, the following conclusions are obtained: (1) The criminal threat as stated in the articles is imprisonment and fines. In addition there is additional criminal or order action against the business entity Article 119 Act Number 32 year 2009 on environmental protection and management. Regarding some factors that are hindering in law enforcement, namely legal means, law enforcement officers, facilities and means, licensing, AMDAL system, Public law awareness of the environment. (2) In the view of Al-Ghazali man has a very heavy function, duty and responsibility as the maintainer of all the SDA (natural resources) that exist on this earth. When people understand the function in this world is to maintain the environment, then automatically, this moral concept will be a preventative step over the real-life CHEST activities that have caused human environmental damage.
\end{abstract}

Keywords: Criminal Environment, CRATE, ethics

\section{PENDAHULUAN}

Segala yang telah diciptakan oleh Tuhan YME adalah seimbang. Kesembangan alam semesta tersebut terjadi apabila terjadi keselarasan diantara makhluk-makhluk ciptaan-Nya.Hal ini dalam istilah ilmu pengetahuan disebut sebagai "hukum alam." Sedangkan dalam konteks agama Islam, dikenal dengan istilah sunnatullah (hukum Allah).

Ketidakseimbangan antara makhluk-makhluk Tuhan YME tersebut tentu saja akan memicu kerusakan alam (bencana) seperti banjir, longsor, polusi, dan lain sebagainya. Adapun pihak yang paling bertanggung jawab atas kerusakan alam adalah manusia. Karena manusia memiliki kebebasan yang sangat luas dalam mengelola alam. Hal ini sebenarnya telah dijelaskan dalam Firman Allah SWT sebagai berikut: 


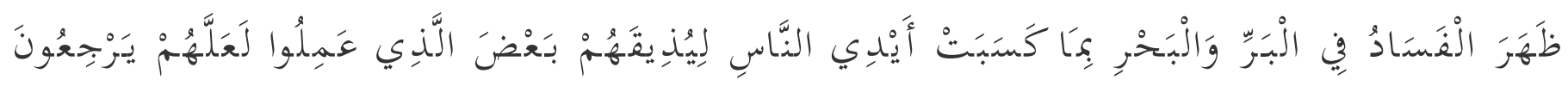

Artinya: "Telah nampak kerusakan di darat dan di laut disebabkan karena perbuatan tangan manusia, supaya Allah merasakan kepada mereka sebahagian dari (akibat) perbuatan mereka, agar mereka kembali (ke jalan yang benar)." (QS. Al-Ruum: 41). ${ }^{1}$

Berdasarkan keterangan ayat di atas, terdapat penegasan bahwa kerusakan lingkungan disebabkan oleh ulah manusia. Dalam konteks hukum positif, maka Negara mengatur sedemikian rupa agar kebebasan manusia itu dibatasi untuk mencegah kerusakan alam di semesta ini.

Persoalan lingkungan sudah menjadi isu dunia. Khususnya di Indonesia, ada banyak sekali persoalan lingkungan yang disoroti oleh hukum pidana. Beberapa kasusnya seperti: (1) Persoalan sampah. Indonesia memproduksi sampah hingga 65 juta ton pada tahun 2016; (2) Persoalan banjir. Kasus tentang banjir ini malah sedang viral di DKI Jakarta yang bahkan merenggut korban jiwa; (3) Pencemaran sungai. Ada puluhan sungai yang tercemar di Indonesia yang salah satunya disebabkan oleh limbah industri; (4) Pemanasan global; (5) Polusi udara. Per tanggal 3 Januari 2017, di Indonesia tercatat102.328.629 kendaraan yang tentu saja mengeluarkan polusi melalui knalpotnya; (6) Rusaknya ekosistem laut: menurut hasil riset Oseanografi LIPI, sekitar 35,15\% terumbu karang di Indonesia dalam kondisi tidak baik; (7) Sulitnya air bersih; (8) Kerusakan hutan: sejak 2010-2015, Indonesia telah kehilangan hutannya hingga 684.000 Ha; (9) Abrasi; dan (10) Pencemaran tanah. ${ }^{2}$

Jika ditilik secara lokal, khususnya di Provinsi Jambi, terdapat beberapa kasus lingkungan diantaranya: kabut asap, kebakaran hutan, banjir, PETI (PenambanganEmas tanpa Ijin), dan lain sebagainya. Hal ini selalu terjadi pengulangan dari tahun ke tahun seolah-olah tidak memiliki solusi yang permanen.

Hipotesis penulis dalam hal ini adalah ada kemungkinan, yaitu: masyarakat tidak mengerti atau memahami apakah tindakannya (dalam konteks perusakan lingkungan) itu termasuk melanggar hukum pidana atau tidak? Dan atas dasar ketidatahuan masyarkat itu, sehingga ada anggapan bahwa apa yang mereka lakukan tidak bertentangan dengan hukum.

Berdasarkan hipotesa di atas, maka penulis tertarik untuk menguraikan apa sebenarnya problematika lingkungan ini dari perspektif hukum pidana. Sehingga diharapkan mampu mengedukasi masyarakat bahwa perbuatan tertentu (perusakan lingkungan) ternyata sudah dapat dikatakan melanggar/tidak melanggar hukum pidana.Lalu, penulis mencoba menawarkan solusi preventif secara moral. Yaitu apa yang dapat ditawarkan oleh filsafat moral agar kasus-kasus lingkungan dalam konteks hukum pidana tersebut dapat diatasi (dicegah) dengan semaksimal mungkin.

\section{METODE PENELITIAN \\ Pendekatan Penelitian}

Pendekatan penelitian yang diterapkan dalam tulisan ini yaitu pendekatan kualitatif, yang secara spesifik bercorak yuridis-empiris.Pendekatan kualitatif adalah cara menghampiri permasalahan penelitian dengan kajian secara komprehensif dan holistic yang mana kemudian hasil kajian itu dituangkan dalam bentuk narasi deskriptif secara objektif dengan tambahan analisis pribadi dalam perspektif yuridis atas persoalan PETI yang telah terjadi secara empris. $^{3}$

\section{Batasan Penelitian}

Tulisan ini difokuskan untuk menjawab dua hal utama, yaitu: (a) Bagaimana perspektif hukum pidana terhadap persoalan lingkungan hidup seperti dalam kasus PETI?(b) Bagaimana solusi atas problem lingkungan hidup (PETI) dari perspektif filsafat moral sebagai upaya preventif?

\section{Sumber dan Jenis Data}

Sumber data untuk tulisan ini berasal dari literatur tertulis (buku, jurnal, artikel, dan sebagainya).Adapun jenis datanya dibagi dua jenis, yaitu primer dan sekunder.Jenis data primer adalah data terkait yang berhasil dihimpun oleh penulis secara pribadi. ${ }^{4}$ Sumber-sumber datanya diambil dari beberapa literature yang relevan.

Jenis data dibagi kepada dua bagian, yaitu: data primer dan data sekunder. Data primer adalah data yang diperoleh secara langsung dari objek penelitian. ${ }^{5}$ Yang menjadi data primer penelitian ini adalah sejumlah literature yang terkait langsung dengan pemaparan tentang lingkungan menurut hukum pidana.

\footnotetext{
${ }^{1}$ Tim Penerjemah Depag RI, al-Quran dan Terjemahnya, (Bandung: Diponegoro, 2008), hlm. 114

${ }^{2} \mathrm{http} / / / \mathrm{www}$. sindonews.com diakses pada 08 Januari 2020

${ }^{3}$ Sugiyono, Memahami Penelitian Kualitatif, (Bandung: Alfabeta, 2014), hlm. 1

${ }^{4}$ Rosady Ruslan, Metode Penelitian: Public Relation dan Komunikasi, (Jakarta: Grafindo Persada, 2003), hlm. 23-24

${ }^{5}$ Rosady Ruslan, Metode Penelitian: Publik Relation dan Komunikasi, (Jakarta: Grafindo Persada, 2003), hlm. 23-24
} 
Kemudian, data sekunder adalah data yang ada dalam pustaka atau data dari tangan kedua atau data yang bukan diusahakan sendiri pengumpulanya oleh peneliti. ${ }^{6}$ Data sekunder penelitian ini adalah literature yang tidak langsung berkenaan dengan isu-isu lingkungan menurut hukum pidana dan filsafat moral, akan tetapi bersifat menunjang untuk digunakan sebagai informasi tambahan.

\section{Teknik Pengumpulan Data}

Teknik pengumpulan data tulisan ini yaitu dokumentasi.Dokumentasi adalah cara mengumpulkan data melalui tulisan, seperti arsip-arsip dan termasuk juga buku-buku tentang pendapat, teori, atau hukum-hukum dan lain-lain yang berhubungan dengan masalah penelitian. ${ }^{7}$

\section{Teknik Analisis Data}

Teknik analisis data yang dipakai dalam tulisan ini adalah content analysis: yaitu pembahasan mendalam terhadap isi suatu permasalahan. ${ }^{8}$ Jadi dalam tulisan ini, dilakukan pemabahasan yang mendalam dan cermat dari setiap literature yang membahas tentang isu lingkungan dalam konteks hukum pidana dan filsafat moral.Kemudian, hasil pencermatan tersebut disusun secara sistematis dalam tulisan jurnal ini.

\section{Definisi Operasional Penelitian}

Definisi operasional dalam tulisan ini disusun agar tidak menimbulkan makna konotatif dari setiap variable judul tulisan ini.Sehingga antara penulis dan pembaca terdapat persamaan lingua franca.Adapun definisi operasionalnya adalah sebagai berikut:

\section{Makna dari Problematika}

Problematika menurut Oka adalah persoalan dengan berbagai kemungkinan cara pemecahan yang mungkin diterapkan tanpa mengevaluasi manakah yang lebih baik dari bentuk-bentuk yang ada itu. ${ }^{9}$ Sedangkan menurut Dandy, adalah masih menimbulkan perdebatan, masih menimbulkan satu masalah yang harus dipecahkan. ${ }^{10}$ Dari penjelasan di atas, maka dapat dikatakan bahwa problematika persoalan-persoalan yang muncul dari berbagai macam faktor yang menimbulkan ganjalan bagi masa depan dan harus segera dicarikan solusi atau penyelesaiannya.

\section{Hakikat Hukum Lingkungan}

Siti Sundari Rangkuti menjelaskan bahwa lingkungan menyangkut penetapan nilai-nilai yang sedang berlaku dan nilai-nilai yang diharapkan diberlakukan di masa mendatang serta dapat disebut "hukum yang mengatur tatanan lingkungan hidup" Hukum ini mengatur hubungan timbal balik antara manusia dengan makhluk hidup lainnya yang apabila dilanggar dapat dikenakan sanksi. ${ }^{11}$

\section{Hakikat Hukum Pidana}

Hukum pidana adalah hukum yang mengatur tentang pelanggaran dan kejahatan terhadap kepentingan umum.Pelanggaran dan kejahatan tersebut diancam dengan hukuman yang merupakan penderitaan atau siksaan bagi yang bersangkutan.

\section{Konsepsi tentang Filsafat Moral (Etika)}

Etika merupakan salah satu pembicaraan inti dalam kajian kefilsafatan.Sehingga tidak mengherankan jika banyak ahli yang merumuskan gagasanya mengenai etika tersebut.Agar konsep etika tersebut menjadi jelas, maka dirasakan perlu untuk merumuskan sekaligus membedakan kata etika itu sendiri dengan berbagai kata yang relevean denganya.Penjelasan mengenai hal tersebut sebagaimana terdapat dalam paragraf di bawah ini.

Etika secara etimologi memiliki arti "Ilmu tentang apa yang baik dan apa yang buruk dan tentang hak dan kewajiban moral (akhlak)." 12 Etika dan moral sama artinya. Tetapi dalam pemakaian sehari-hari ada sedikit perbedaan.Kata moral dipakai dipakai untuk perbuatan yang sedang dinilai.Sedangkan kata etika digunakan untuk pengkajian sistem nilai-nilai yang ada. Dalam hal ini, Zubair mengatakan sebagai berikut:

\section{${ }^{6}$ Ibid., hlm. 29}

${ }^{7}$ Suharsimi Arikunto, Manajemen Penelitian (Jakarta: P21PTK, 1993), hal. 202 lihat pula Sanafiah Faisal, Penelitian Kualitatif Dasar-dasar dan Aplikasi (Malang: Yayasan Asih Asuh, 1990), hlm. 46

${ }^{8}$ http:www.researchgate.net

${ }^{9}$ I Gusti Ngurah Oka, Problematika Bahasa dan Pengajaran Bahasa Indonesia, (Jakarta: UI Press, 1974), hlm. 15

${ }^{10}$ Dandy, Kamus Besar Bahasa Indonesia, (Jakarta: Gramedia Pustaka Utama, 2008), 1103

${ }^{11}$ Siti Sundari Rangkuti, Hukum Lingkungan dan Kebijaksanaan Lingkungan Naional, (Surabaya: Universiti Press, 2000),

hlm. 2

${ }^{12}$ Dandy Sugono, Kamus Besar Bahasa Indonesia, (Jakarta: Gramedia Pustaka, 2014), hlm. 383 
Etika secara etimologik berasal dari kata ethos yang berarti watak kesusilaan atau adat. Identik dengan perkataan moral yang berasal dari kata Latin yaitu mos yang dalam bentuk jamaknya adalah mores artinya adat atau cara hidup. ${ }^{13}$

Kata moral selalu mengacu pada baik buruknya manusia sebagai manusia.Jadi, bukan baik-buruknya begitu saja; misalnya sebagai dosen, tukang masak, pemain bulu tangkis, atau penceramah, melainkan sebagai manusia.Bidang moral adalah bidang kehidupan manusia dilihat dari segi kebaikanya sebagai manusia."Norma-norma moral adalah tolok ukur untuk menentukan betul salahnya tindakan manusia dilihat dari segi baik-buruknya sebagai manusia dan bukan sebagai pelaku peran tertentu dan terbatas."14

Berdasarkan analisa Suseno di atas, dapat diketahui bahwasanya kata moral cenderung untuk memberikan penilaian apakah suatu hal itu dapat dianggap baik atau tidak baik.Sedangkan kata etika lebih menitikberatkan perhatianya kepada analisa atas nilai-nilai moral yang terkandung di dalam sesuatu hal.

Kata etika memiliki berbagai makna yang mirip dengan kata-kata lainya yang semakna.Oleh sebab itu, dirasa perlu bagi peneliti untuk menguraikan kata-kata tersebut untuk memperoleh ketegasan makna dari kata etika itu sendiri. Adapun hasil penelusuran literatur mengenai kata-kata yang dimaksud telah peneliti sajikan dalam bentuk tabel di bawah ini:

Tabel 1. Kata-kata yang Berdekatan dengan Etika

\begin{tabular}{|c|c|c|}
\hline No & Kata & Makna \\
\hline 1 & Etik & $\begin{array}{l}\text { Kumpulan asas atau nilai yang berkenaan dengan akhlak; Nilai mengenai benar dan salah yang dianut } \\
\text { suatu golongan atau masyarakat. } 15\end{array}$ \\
\hline 2 & Etiket & $\begin{array}{l}\text { Tata cara adat sopan santun dan sebagainya, dalam masyarakat beradab dalam memilihara hubungan baik } \\
\text { antara sesama manusia. }{ }^{16}\end{array}$ \\
\hline 3 & Etis & Berhubungan atau sesuai dengan etika; Sesuai dengan asas perilaku yang disepakati secara umum. ${ }^{17}$ \\
\hline 4 & Moral & $\begin{array}{l}\text { Ajaran tentang baik buruk yang diterima umum mengenai perbuatan, sikap, kewajiban, dan sebagainya; } \\
\text { akhlak budi pekerti, susila; Kondisi mental yang membuat orang tetap berani, bersemangat, bergairah, } \\
\text { berdisiplin, dan sebagainya; Isi hati atau keadaan perasaan sebagaimana terungkap dalam perbuatan. }{ }^{18}\end{array}$ \\
\hline 5 & Moralisme & $\begin{array}{l}\text { Filsafat yang menitikberatkan pada moral dan menganggap nilai kesusilaan sebagai nilai yang paling } \\
\text { luhur sehingga kewajiban manusia terutama adalah menyelenggarakan nilai kesusilaan itu, sedangkan } \\
\text { ilmu pengetahuan dan sebagainya menjadi tidak penting. }{ }^{19}\end{array}$ \\
\hline
\end{tabular}

\section{HASIL DAN PEMBAHASAN}

Aktivitas PETI di Jambi

Berdasarkan penelusuran peneliti terhadap berbagai literature ilmiah, dapat dipetakan bahwa peningkatan aktivitas PETI dari tahun ke tahun terus mengalami peningkatan.Hal ini dapat diukur melalui semakin bertambahnya penyitaan unit mesin PETI yang berhasil diringkus oleh pihak kepolisian.Data menunjukkan bahwa aktivitas PETI di Jambi melonjak sejak tahun 2000. Hasilnya dapat dilihat pada grafik di bawah ini:

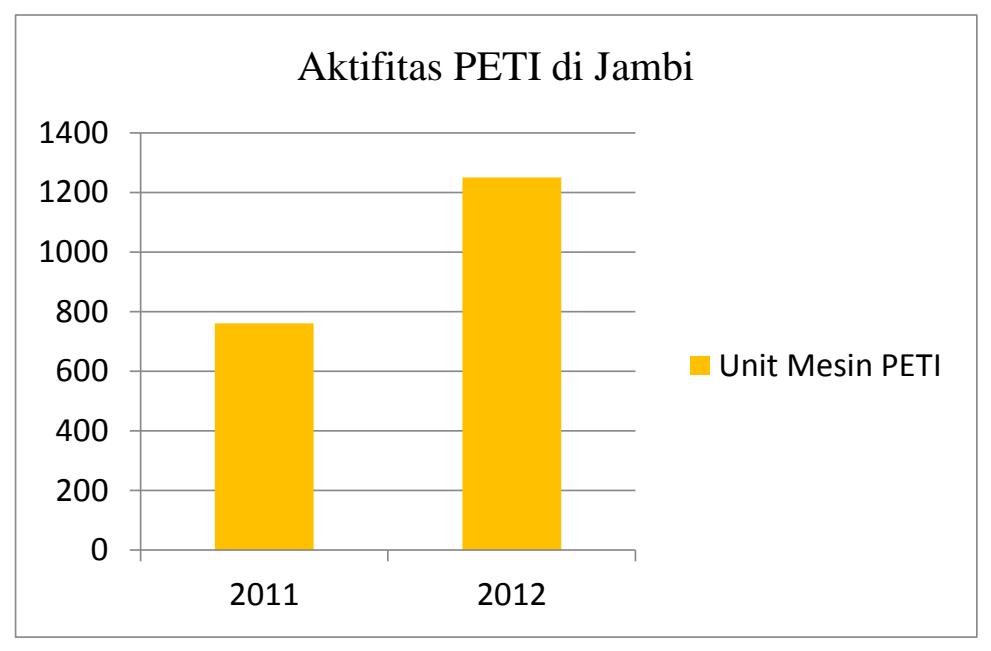

\footnotetext{
${ }^{13}$ Ahmad Charis Zubair, Kuliah Etika, (Jakarta: Rajawali, 1987), hlm. 13

${ }^{14}$ Frans Magnis Suseno, Etika Dasar: Masalah-masalah Pokok Filsafat Moral (Yogyakarta: Kanisisus, 2005), hlm. 18

${ }^{15}$ Dandy Sugono, Kamus Besar Bahasa Indonesia, (Jakarta: Gramedia Pustaka, 2014), hlm. 383

${ }^{16}$ Ibid

${ }^{17}$ Ibid

${ }^{18}$ Ibid., hlm. 929

${ }^{19}$ Ibid., hlm. 329
} 
Berdasarkan data di atas, maka diketahui bahwasanya unit mesin PETI yang berhasil diamankan petugas di tahun 2011 adalah sebanyak 760 unit, sedangkan di tahun berikutnya, hanya berselang 1 tahun, yaitu pada 2012 melonjak tajam diangka 1.250 unit mesin PETI. Ini menunjukkan bahwa kegiatan PETI di Provinsi Jambi memang sangat banyak jumlahnya.Peta persebaran kasus PETI di Provinsi Jambi terjadi secara spesifik di lima kabupaten, yaitu dijelaskan dalam tabel di bawah ini:

\begin{tabular}{cc}
\hline No & Lokasi \\
\hline 1 & Batanghari \\
2 & Bungo \\
3 & Merangin \\
4 & Tebo \\
5 & Sarolangun \\
\hline \multicolumn{2}{l}{ Sumber: Olahan data primer }
\end{tabular}

PETI disisi para pelakunya, boleh jadi memberikan manfaat ekonomi-praktis, akan tetapi pada saat yang sama, PETI juga membawa dampak negative bagi lingkungan, berupa: terjadinya kerusakan ekosistem sungai.Oleh sebab itu, penting untuk menekan aktivitas illegal ini agar tidak terjadi kerusakan yang lebih parah di kemudian hari.Lalu, perspektif hokum yuridis-empiris dirasakan amat perlu untuk melihat persoalan ini.

\section{Masalah PETI dalam Perspektif Hukum Pidana}

Sanksi pidana adalah jalan yang terakhir yang dapat ditempuh ketika tidak mendapatkan solusi lain dalam kasus-kasus lingkungan. Sanksi pidana ini dijatuhkan kepada siapa saja yang telah melanggar hukum lingkungan yang telah disusun sedemikian rupa.Tujuannya yaitu untuk mendidik atau mengedukasi atau membuat jera para pelaku hukum (perusahaan).Selain itu fungsinyajuga untuk mencegah atau menghalangipelaku pontensial agar tidak melakukanperilaku yang tidak bertanggung jawabterhadap lingkungan hidup, seperti kasus PETI.Untuk bisamenjatuhkan pidana untuk kasuslingkungan pada perusahaan maka jugaberlaku peraturan-peraturan sepertikasus pidana lainnya yaitu asas legalitas;maksudnya harus berdasarkan hukum yang ada pada saat perbuatan itudilakukan dan harus terbuktikesalahannya. ${ }^{20}$

Ketika terbukti sebuah tindakan tersebut masuk sebagai pelanggaran pidana terkait lingkungan, maka sanksi atas tindakan tersebut telah di atur dalam ketentan pidana yaitu dalam Pasal 97 sampai dengan Pasal120 UndangUndang Nomor 32 Tahun 2009 tentang Perlindungan dan Pengelolaan Lingkungan Hidup.Pasal 98 Undang-Undang Nomor 32 Tahun 2009 tentang Perlindungan dan Pengelolaan Lingkungan Hidup menyatakan:

a. Setiap orang yang dengan sengaja melakukan perbuatan yang mengakibatkan dilampauinya baku mutu udara, baku mutu air, baku mutu air laut, atau kriteria baku kerusakan lingkungan hidup, dipidana dengan penjara paling singkat 3 ( tiga ) tahun dan paling lama 10 (sepuluh) tahun dan denda paling sedikit Rp. 3.000.000.000,00 (tiga miliar rupiah) dan paling banyak Rp. 10.000.000.000,00 (sepuluh miliar rupiah).

b. Apabila perbuatan sebagaimana dimaksud pada ayat (1) mengakibatkan orang luka dan/atau bahaya kesehatan manusia, dipidana dengan pidana penjara palingsingkat 4 (empat) tahun dan paling lama 12 (dua belas) tahun dan denda paling sedikit Rp. 4.000.000.000,00 (empat miliar rupiah) dan paling banyak Rp. 12.000.000.000,00 (dua belas miliar rupiah).

c. Apabila perbuatan sebagaimana dimaksud pada ayat (1)mengakibatkan orang luka berat ataumati, dipidana dengan pidanapenjara paling singkat 5 (lima) tahundan paling lama 15 (lima belas)tahun dan denda paling sedikitRp. 5.000.000.000,00 (lima miliarrupiah) dan paling banyakRp. 15.000.000.000,00 (lima belasmiliar rupiah).

Apabila tindak pidana lingkunganhidup dilakukan oleh atas nama badanusaha atau perusahaan maka tuntutanpidana dan sanksi pidana dijatuhkankepada badan usaha atau orang yangmemberi perintah untuk melakukantindak pidana tersebut atau orang yangbertindak sebagai pemimpin kegiatandalam tindak pidana tersebut (Pasal 116ayat (1) dan (2) Undang-Undang Nomor32 Tahun 2009 tentang Perlindungandan Pengelolaan Lingkungan Hidup).Berdasarkan keterangan ini, maka dapat diketahui bahwasanya apabila kasus pidana lingkungan dilakukan oleh perusahaan, maka yang bertanggung jawab adalah pimpinan perusahaan karena ia adalah orang yang bertanggung jawab dan pengambil keputusan/kebijakan dari setiap tindakan yang dilakukan oleh perusahan tersebut.

Ancaman pidana sebagaimanatercantum dalam pasal-pasal Undang-Undang Nomor 32 Tahun 2009 tentangPerlindungan dan PengelolaanLingkungan Hidup adalah pidanapenjara dan denda. Selain itu adapidana tambahan atau tindakan tatatertib terhadap badan usaha dalam Pasal 119 berupa:

a. Perampasan keuntungan yangdiperoleh dari tindak pidana.

${ }^{20}$ Nina Herlina, Permasalahan Lingkungan Hidup dan Penegakan Hukum Lingkungan di Indonesia, (t.tt: Universitas Galuh Press, t.th), hlm. 10 
b. Penutupan seluruh atau sebagiantempat usaha dan/atau kegiatan.

c. Perbaikan akibat tindak pidana.

d. Pewajiban mengerjakan apa yang dilalaikan tanpa hak.

e. Penempatan Perusahaan dibawah pengampuan paling lama 3 (tiga) tahun.

Dalam penegakan hukumlingkungan hidup terdapat berbagaihambatan yang mengakibatkan tidakefektivitasnya faktor pendukung dalampenegakan hukum lingkungan PETI ini. Banyakperaturan-peraturan yang telahdikeluarkan oleh pemerintah, namunpelaksanaanya dilapangan masihhambatan yang ditemui yaitu sebagai berikut: ${ }^{21}$

\section{Hambatan dari Segi Sarana Hukum}

Sarana hukum merupakanfaktor kendala dan hambatan dalampenegakan hukum lingkungan.Berbagai kebijakan operasional yangdikeluarkan seringkali tidak konsistendengan prinsip-prinsip perlindungandan pengelolaan lingkungan hidup.Didalam Undang-Undang Nomor 32Tahun 2009 maupun Undang-undang yang berkaitan denganpengelolaan lingkungan hiduplainnya. Bahwa dalam upayapenegakan hukum lingkungan, faktormanusia sebagai pelaksanannyaakan lebih banyak membentuk keberhasilan penegakan hukum dibandingkan dengan faktor hukum itu sendiri.

\section{Hambatan dari SegiAparat Penegak Hukum}

Banyak kasus-kasuslingkungan terkendala dikarenakanjumlah aparat penegak hukumprofesional yang mampu menanganikasus-kasus lingkungan masihsangat terbatas.Disamping ituadalah mustahil kiranya kitamengharapkan para penegak hukumitu dapat menguasai berbagai aspeklingkungan.Karena lingkungan hidupmencakup aspek yang sangat luasdan kompleks yang berkenaandengan berbagai disiplin ilmu.Keterbatasan pengetahuan danpemahaman aspekaspeklingkungan oleh penegak hukummenjadi faktor kendala yang sangatdominan dalam upaya untukmenciptakan kesamaan presepsipenanganan perkara lingkungan.Artinya di sini, ada beberapa kasus terjadi, dimana pihak yang berwenang (oknum) dalam menangani kasus lingkungan terkadang tidak memiliki wawasan yang cukup tentang lingkungan.Sehingga ketika dihadapkan pada satu kasus, seringkali penangan kasus tersebut tidak optimal dalam penindakannya, atau bahkan adanya kasus immoral dimana aparat penegak hokum justeru ikut bermain peran dengan para pelaku PETI demi kepentingan pribadi.

\section{Hambatan dari Segi Fasilitas dan Sarana}

Fasilitas dan sarana adalahalat untuk mencapai tujuanpenegakan hukum lingkungan.Ketiadaan atau keterbatasan fasilitasdan sarana penunjang (termasuk dana), akan sangatmempengaruhi keberhasilanpenegakan hukum lingkungan.bahwa kenyataan menunjukandalam penanganan kasus-kasuslingkungan akan melibatkan berbagai perangkat berteknologi canggih (peralatan laboratorium), yang untuk kepentingan operasionalisasinya memerlukan tenaga ahli dan biaya cukup mahal.

\section{Hambatan dari Segi Perizinan}

Perizinan mememang menjadisalah satu masalah yang lebihbanyak memberi peluang bagi berkembangnya masalah lingkungan ketimbang membatasinya.SebabPasal 36 Undang-Undang Nomor 32Tahun 2009 masih bisa dilewatibegitu saja oleh pengusaha.Dalam hal ini, kadangkala perusahaan tidak taat asas perundang-undangan yang berlaku. Berbelit-belitnya proses perijinan, membuat perusahaan mengambil jalan pintas dan langsung saja beroperasi tanpa pengecekan dan asesmen terlebih dahulu.

\section{Hambatan dari Segi Sistem Analisis Mengenai Dampak Lingkungan (AMDAL)}

Dalam prakteknya, AMDAL lebih mengarah pada penonjolanpemenuhan ketentuan administrative daripada subtantifnya. Artinyapesatnya permintaan akan AMDAL merupakan mata rantai kewajibandalam urusan perizinan dalam suatuusaha atau dipandang sebagai performa untuk mendapatkan akadkredit atau izin investasi. Prosestransparansi dan mekanismeketerbukaan dokumen AMDAL bagi masyarakat tidak berjalan sesuai harapan, bahkan masyarakat (yang terkena dampak) tidak mengetahui secara pasti adanya suatu aktifitas kegiatan.

\section{Hambatan dari SegiKesadaran Hukum Masyarakat}

Terhadap Lingkungan Kepatutan dan ketaatan kepada ketentuan hokum (lingkungan), merupakan indicator kesadaran hukum masyarakat. Peran serta masyarakat, menurut undang-undang pengelolaan lingkungan hidup merupakan komponen utama, disamping keberadaan penegak hukum, untuk tercapainya tujuan hukum melalui sarana penegakan hukum, dengancara melakukan penegakan hokum lingkungan hidup. Masih terbatasnya kesadaran hukum 
masyarakat terhadap lingkungan disebabkan keawaman masyarakat terhadap aspek lingkungan dan tidak mengetahui akibat yang akan timbul bila melakukan pencemaran danperusakan lingkungan. Untuk itu diperlukan usaha-usaha seperti penyuluhan, bimbingan, teladan danketerlibatan masyarakat dalam penanggulangan masalah lingkungan.Untuk itu, peningkatan kegiatan penegakan hukum yang berdimensi edukatif-persuasif dan preventif perlu ditingkatkan lagi.

Kondisi ini juga ikut diperparah dengan adanya sikap masyarakat yang cenderung apatis terhadap lingkungan hidup. Pelaku PETI tidak memiliki orientasi jangka panjang terhadap apa yang mereka lakukan. Mereka cenderung abai dan hanya mementingkan keuntungan ekonomis yang praktis yang dapat mereka peroleh dengan sebesarbesarnya tanpa sedikitpun memikirkan kelangsungan hidup lingkungan sungai yang mereka rusak dengan adanya aktivitas PETI tersebut.

\section{Solusi Masalah PETI dalam Tinjauan Etis}

Dari hasil pembahasan pada poin satu di atas, dikatakan bahwa kerusakan lingkungan yang ditimbulkan dengan adanya kasus PETI dari aspek preventif masih perlu untuk ditingkatkan kembali.Artinya tidak dapat hanya dengan mengambil langkah kuratif dengan hukum pidana lingkungan semata-mata. Oleh sebab itu, dalam pembahasan ini, penulis akan memaparkan solusi preventif atas kerusakan lingkungan akibat PETI tersebut dari perspektif etis yang dikemukakan oleh Al-Ghazali. Untuk mencegah kerusakan lingkugan alam, termasuk pada kasus-kasus kerusakan alam akibat adanya kegiatan PETI ini, menurut Al-Ghazali secara etika, maka ada beberapa hal yang harus dipahami oleh manusia, yaitu sebagai berikut:

\section{Manusia Harus Mengerti Fungsinya Dibumi}

Fungsi penciptaan manusia oleh Allah SWT adalah agar ada makhluk-Nya yang mampu untuk memikirkan tentang segala penciptaan, baik yang ada di bumi maupun langit ataupun diantara keduanya dengan tujuan pengetahuan akan penciptaan itu semua berujung kepada pengetahuan akan pengenalan adanya Sang Pencipta yaitu Allah SWT. ${ }^{22}$

Ketika manusia mengerti fungsinya di dunia ini adalah untuk mengenal alam, mengenal makhluk Allah SWT, maka akan terwujud keharmonisan alam. Manusia akan menjaga keseimbangan alam dan tidak terjadi eksploitasi alam secara berlebihan dan mengakibatkan kerusakan. Manusia yang serakah dengan jalan melakukan penambangan emas ilegal, pada akhirnya hanya akan merusak lingkungan. Kalau manusia mengerti bahwa dirinya adalah yang bertanggung jawab untuk memelihara atau menjaga alam, maka tidak akan mungkin ada niat manusia tersebut untuk sembarangan menggali emas, seperti yang terjadi dalam kasus PETI ini.

\section{Manusia Bertanggung Jawab Mengatur Alam}

Manusia mempunyai tugas dan tanggung jawab yang sangat berat yaitu "Abdul Allah " (hamba Allah) satu sisi dan sekaligus sebagai "Kholifah fil Ardli" (wakil Allah atau pemelihara alam di muka bumi). ${ }^{23}$ Manusia diciptakan setelah sebelumnya direncanakan untuk mengemban satu tugas sebagai khalifah di muka bumi ini. Ia dibekali Tuhan dengan potensi dan kekuatan positif lewat akalnya untuk menjagaalam. Sebagaimana firman Allah dalam Al-Qur'an Surat Al-Baqarah ayat 30 yang berbunyi:

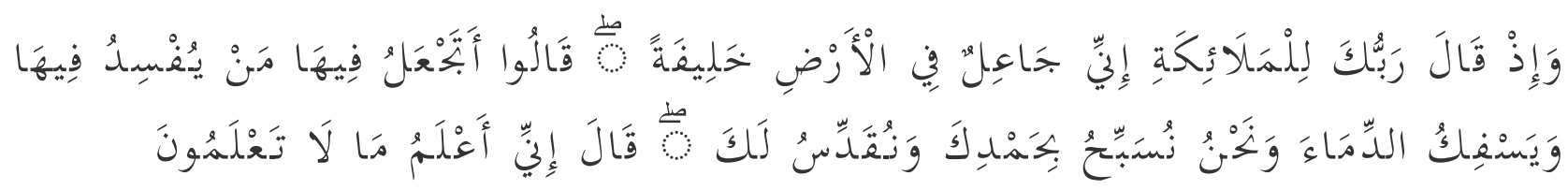

Artinya: "Ingatlah ketika Tuhanmu berfirman kepada Para Malaikat: 'Sesungguhnya aku hendak menjadikan seorang khalifah di muka bumi." mereka berkata: "Mengapa Engkau hendak menjadikan (khalifah) di bumi itu orang yang akan membuat kerusakan padanya dan menumpahkan darah, Padahal Kami Senantiasa bertasbih dengan memuji Engkau dan mensucikan Engkau?' Tuhan berfirman: 'Sesungguhnya aku mengetahui apa yang tidak kamu ketahui.' (QS. Al-Baqarah: 30). ${ }^{24}$

Ayat di atas memberikan penegasan akan penugasan Allah SWT kepada manusia sebagai mandataris Allah dan pada hakekatmnya eksistensi manusia dalam kehidupan ini adalah membangun dan mengelola dunia tempat hidupnya ini sesuai dengan kehendak penciptanya. Tugas kekhalifahan tersebut memang sangat berat.

${ }^{22}$ Imam Al-Ghazali, terj. Abu Jafar al_Qalami, Ringkasan Ihya Ulum al-Din, (Surabaya: Gita Media Press, 2003), hlm.

${ }^{23}$ M. Quraisy Shihab, Membumikan al-Qur'an, 'Fungsi Dan Peran Wahyu Dalam Kehidupan Masyarakat”, (Bandung, Mizan, 2003), hlm. 158

${ }^{24}$ Tim Penerjemah Depag RI, al-Quran dan Terjemahnya, (Bandung: DIponegoro, 2008), hlm. 34 


\section{SIMPULAN}

Dari uraian di atas, dapat disimpulkan hal penting sebagai berikut:

1. Ancaman pidana pelaku PETI sebagaimana tercantum dalam pasal-pasal adalah pidana penjara dan denda. Selain itu ada pidana tambahan atau tindakan tata tertib terhadap badan usaha Pasal 119 Undang-Undang Nomor 32 Tahun 2009 tentang Perlindungan dan Pengelolaan Lingkungan Hidup. Mengenai beberapa faktor yang menghambat dalam penegakan hukumpada kasus PETI, yaitu: hambatan-hambatan dari segi sarana hukum, aparat penegak hukum, fasilitas dan sarana, perizinan, sistem Amdal, serta kesadaran hukum masyarakat (pelaku PETI) yang dangkal terhadap lingkungan.

2. Dalam pandangan Al-Ghazali manusia mempunyai fungsi, tugas dan tanggung jawab yang sangat berat yaitu sebagai hamba Allah dan sebagai khalifah di bumi.Sebagai khalifah artinya manusia itu sebagai pemimpin, pemakmur bumi dan pemelihara alam. Ketika manusia memahami fungsinya di dunia ini adalah untuk memelihara lingkungan, maka secara otomatis, konsep moral ini akan menjadi langkah preventif atas kerusakan lingkungan alam oleh manusia itu sendiri.

\section{DAFTAR PUSTAKA}

\section{Buku}

Anonim.al-Quran dan Terjemahnya.Bandung: Diponegoro, 2008

Al-Ghazali.terj. Abu Jafar al_Qalami, Ringkasan Ihya Ulum al-Din, Surabaya: Gita Media Press, 2003

Arikunto, Suharsimi. Manajemen Penelitian Jakarta: P21PTK, 1993

Faisal,Sanafiah Penelitian Kualitatif Dasar-dasar dan Aplikasi.Malang: Yayasan Asih Asuh, 1990

Herlina, Nina Permasalahan Lingkungan Hidup dan Penegakan Hukum Lingkungan di Indonesia.t.tt: Universitas Galuh Press, t.th

Marbun, B.N. Kamus Politik.Jakarta: Pustaka Sinar Harapan. 1996

Mulkhan,Abdul Munir Mencari Tuhan dan Tujuh Jalan Kebebasan: Sebuah Esai Pemikiran Imam Al-Ghazali.Jakarta: Bumi Aksara. 2001

Oka, I Gusti Ngurah.Problematika Bahasa dan Pengajaran Bahasa Indonesia, Jakarta: UI Press, 1974

Rangkuti, Siti Sundari.Hukum Lingkungan dan Kebijaksanaan Lingkungan Naional.Surabaya: Universiti Press, 2000

Ruslan, Rosady. Metode Penelitian: Public Relation dan Komunikasi.Jakarta: Grafindo Persada, 2003

Satoto, Sukamto. Pengaturan Eksistensi dan Fungsi Badan Kepegawaian Negara, Yogyakarta: Hanggar Korektor, t.th.

Shihab, M. Quraisy.Membumikan al-Qur'an,"Fungsi Dan Peran Wahyu Dalam Kehidupan Masyarakat."Bandung, Mizan, 2003

Sugiyono.Memahami Penelitian Kualitatif.Bandung: Alfabeta, 2014

Sugono, Dandy Kamus Besar Bahasa Indonesia.Jakarta: Gramedia Pustaka, 2014

Suseno, Frans Magnis.Etika Dasar: Masalah-masalah Pokok Filsafat Moral Yogyakarta: Kanisisus, 2005

Zubair,Ahmad Charis.Kuliah Etika.Jakarta: Rajawali. 1987

\section{Internet}

http://www.sindonews.com diakses pada 08 Januari 2020

http:www.researchgate.net 